"Applying a two-stage TOPSIS approach and stepwise regression in evaluating bank performance: evidence from Turkish banks"

\begin{tabular}{|c|c|}
\hline AUTHORS & 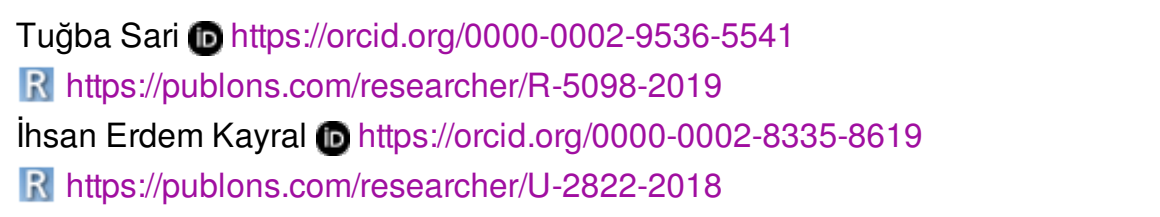 \\
\hline ARTICLE INFO & $\begin{array}{l}\text { Tuğba Sari and insan Erdem Kayral (2019). Applying a two-stage TOPSIS } \\
\text { approach and stepwise regression in evaluating bank performance: evidence } \\
\text { from Turkish banks. Banks and Bank Systems, 14(4), 114-125. } \\
\text { doi:10.21511/bbs.14(4).2019.11 }\end{array}$ \\
\hline DOI & http://dx.doi.org/10.21511/bbs.14(4).2019.11 \\
\hline RELEASED ON & Friday, 13 December 2019 \\
\hline RECEIVED ON & Thursday, 08 August 2019 \\
\hline ACCEPTED ON & Monday, 02 December 2019 \\
\hline LICENSE & $\begin{array}{l}(c) E Y \\
\text { This work is licensed under a Creative Commons Attribution } 4.0 \text { International } \\
\text { License }\end{array}$ \\
\hline JOURNAL & "Banks and Bank Systems" \\
\hline ISSN PRINT & $1816-7403$ \\
\hline ISSN ONLINE & $1991-7074$ \\
\hline PUBLISHER & LLC "Consulting Publishing Company "Business Perspectives" \\
\hline FOUNDER & LLC "Consulting Publishing Company "Business Perspectives" \\
\hline
\end{tabular}

NUMBER OF REFERENCES

36
NUMBER OF FIGURES

1

\section{E=-}

NUMBER OF TABLES

10

(C) The author(s) 2022. This publication is an open access article. 


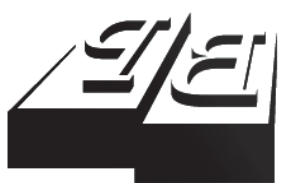

BUSINESS PERSPECTIVES

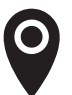

LLC "CPC "Business Perspectives" Hryhorii Skovoroda lane, 10, Sumy, 40022, Ukraine

www.businessperspectives.org

Received on: $8^{\text {th }}$ of August, 2019 Accepted on: $2^{\text {nd }}$ of December, 2019

(c) Tuğba Sari,

İhsan Erdem Kayral, 2019

Tuğba Sari, Ph.D., Assistant Professor, Department of Management Information Systems, Faculty of Social Sciences and Humanities, Konya Food and Agriculture University, Turkey.

İhsan Erdem Kayral, Ph.D., Assistant Professor, Department of Economics, Faculty of Social Sciences and Humanities, Konya Food and Agriculture University, Turkey.

\section{() (i)}

This is an Open Access article, distributed under the terms of the Creative Commons Attribution 4.0 International license, which permits unrestricted re-use, distribution, and reproduction in any medium provided the original work is properly cited.

\title{
APPLYING A TWO-STAGE TOPSIS APPROACH AND STEPWISE REGRESSION IN EVALUATING BANK PERFORMANCE: EVIDENCE FROM TURKISH BANKS
}

\begin{abstract}
As a crucial component of the financial sector, banks play an intermediary role in creating and providing financial services to customers. Therefore, the evaluation of banking sector activity is important for stakeholders and managers. This paper investigates the key criteria in analyzing bank performance and efficiency and the relative performance of Turkish banks in terms of the pre-determined criteria during 2008-2018. This study aims to introduce a robust and easy-to-calculate mathematical model for estimating bank performance using stepwise regression and TOPSIS methods. The TOPSIS ranking of banks from the best to the worst allows establishing that the bank with the highest mean score is Akbank (AB), while Ziraat Bank (ZB) and Garanti Bank (GB) follow $\mathrm{AB}$ over the period. The results of the stepwise regression analysis show that managing non-performing loans and expenses (both personnel and interest expenses) are critical to high performance in the banking sector.
\end{abstract}

\section{Keywords}

\section{JEL Classification}

\section{INTRODUCTION}

The importance of the banking sector to the national and global economies is great. Since banks convert the public's deposits and savings into businesses, they are the main capital providers for infrastructure, innovation and development. Besides, banks and other financial institutions contribute to job creation and overall well-being. Therefore, a well-functioning banking sector plays an important role in stabilizing the financial markets. A strong and efficient banking system accelerates economic growth and serves as an emergency signal against financial crises and helps to overcome the effects of such negative shocks.

Today's highly competitive business environment forces banks to use their resources effectively (Doğan, 2013). These conditions have led to the necessity for bank managers, investors, customers and policy makers to compare the activities of banks with each other. To compare good and bad practices and to see overall improvement in the banking sector, accurate assessment of bank performance is essential. Measurement of bank's financial performance is important for several reasons: improving management performance, providing information on comparisons between the best and the worst practices for stakeholders, investigating the impact of some macroeconomic changes on bank performance to establish appropriate policies (Berger \& Humphrey, 1997). 
For the reasons mentioned above, measuring the efficiency and effectiveness of banks is of high interest to researchers. While the early studies on this topic have focused on commercial banks in developed countries, more attention has been paid to bank performance and efficiency in developing countries and transition economies in the last decade. In addition, the devastating effects of the 2008 global crisis have increased the importance of analyzing efficiency and effectiveness in the financial sector.

Although there is a common sense that how important it is to evaluate bank performance, the methods and performance indicators may vary widely. Financial ratios provide useful information for evaluating bank performance and efficiency. The basic financial ratios related to efficiency are return on equity (ROE) and return on assets (ROA) (Chao, Yu, \& Wu, 2015; Svitalkova, 2014; Titko \& Jureviciene, 2014; Lee \& Kim, 2013). Although in most cases the variables encompass assets quality, capital strength, earnings, and liquidity, the number of variables included in research may differ significantly in the literature (Fethi \& Pasiouras, 2010). The selection of variables and the methodology is directly related to the purpose of the model.

During the 1980s, many structural changes were seen in the Turkish economy such as regulations in the financial and banking system. Within this framework, the interest rate ceiling system was abandoned and the exchange rate regime was reorganized. The Interbank Money Market, the Capital Markets Board and the Istanbul Stock Exchange were established to arrange financial markets and banking systems. In 1989, the convertibility of the Turkish Lira was achieved with the Act of 32. Despite these positive regulations, new structural problems commenced in the financial and banking system. With this act, Turkish banks increased their foreign currency debts and loans to use arbitrage opportunities. This move made Turkish banks vulnerable to speculative shocks (Akyüz \& Boratav, 2003; Alper \& Öniş, 2004; Sayılgan \& Yıldırım, 2009).

As a result of liberalization in the 1980s, the Turkish economy faced a set of crises in 1994, 1999 and 2001. Since the Turkish banking system was not deep enough in those years, they were affected by these crises seriously and many banks went bankrupt. After the 1999 crisis, the Banking Regulation and Supervision Agency (BRSA) was established. It played an active role in strengthening the banking system after the 2001 crisis. BRSA and the Saving Deposits Insurance Fund (SDIF) rearranged and restructured the banking system. While banks were the main source of financing government deficit in the 1990s, they started to be a financial intermediary between investors and sectors (Sekmen, Akkus, \& S1klar, 2017). After these transformations in the banking sector, Turkish banks' efficiencies have been followed by investors and researchers.

This study aims to introduce a model to compare the financial performance of Turkish banks using the financial criteria, which can be commonly found in the related literature. The sample financial data belongs to 10 Turkish commercial banks for the period of 2008-2018. A two-stage TOPSIS (Technique for Order Performance by Similarity to Ideal Solution) analysis with stepwise regression technique is carried out to evaluate the relative bank performance. As an initial step of analysis, bank performance is determined by using a set of financial ratios (criteria). Following the first step analysis, stepwise regression is applied to data to determine the criteria that explain the performance better. Afterwards, the bank performance is recalculated by the TOPSIS technique using these refined criteria. The banks are then re-ranked via strengthened performance analysis to define and compare the best performing banks and the worst performing banks.

This study extends the existing literature by checking the contribution of each variable simultaneously to a more flexible and informative model. To the authors' knowledge, this is the first application of a hybrid methodology of TOPSIS and stepwise regression in the literature.

The study is structured as follows: The first section includes a review of the existing literature related to bank effectiveness and efficiency. Examples of various methods are introduced. In the second section, the research methodology is explained. The data are analyzed; the results are explained and discussed in the tables in the third section. The conclusion of the study and further studies are discussed in the last section. 


\section{LITERATURE REVIEW}

There are various methodologies utilized to measure bank efficiency and effectiveness in literature. Data envelopment analysis (DEA) is one of the most important non-parametric analysis techniques used to examine this issue. Wang, Huang, Wu, and Liu (2014) proposed the network DEA method to determine Chinese commercial banks' efficiency after the Chinese banking reform. Paradi, Rouatt, and Zhu (2011) compared the branch efficiencies of a major Canadian Bank. They pointed out that three significant branch performance indicators are production, intermediation function and profitability. Fukuyama and Matousek (2011) examined the three types of efficiencies in 25 Turkish banks using a twostage DEA network system. According to their study, the performance scores of the banks reflect Turkish economic conditions before, during and after the financial crisis. Fernandes, Stasinakis, and Bardarova (2017) analyzed the efficiency of European banks via DEA, which is utilized on a Malmquist productivity index. They applied truncated regression to get bias-corrected results in the second step and stated that bank performance positively related to profit and capital risk. Salim, Arjomandi, and Seufert (2016) used a two-stage DEA analysis to analyze the interactions between the performances of Australian banks and the corporate governance in Australia. They found that the performances of Australian banks are positively affected by the board size. Furthermore, committee meetings serve as an important factor for performance scores. Staub, Souza, and Tabak (2010) investigated the impact of ownership on the Brazilian banks' efficiency using a DEA approach. They revealed that domestic-private and foreign-private banks are less effective than state banks.

Another frontier analysis used in evaluating bank performance and efficiency is parametric stochastic frontier analysis (SFA). Hsiao, Shen, and Bian (2015) investigated the efficiency of Chinese banks using the SFA method and pointed out that Chinese banks' performance acquired the foreign banks as cost efficiency after financial reform. Another study conducted with SFA is one performed by Dong, Firth, Hou, and Yang (2016). This study investigated the ownership effect on the bank performance in China and found out that foreign banks and state-owned banks are the most cost-effective and profit-efficient banking groups, respectively.

In the literature, multi-criteria decision making methods are effectively used in evaluating bank performance and efficiency. Mandic, Delibasic, Knezevic, and Benkovic (2014) suggested a model using TOPSIS and FAHP methods in measuring bank performance in Serbia. This model included eight criteria such as: portfolio, cash, earnings before tax, equity, sources, liquidity, net interest income, and net income from core business. Seçme, Bayrakdaroğlu, and Kahraman (2009) integrated FAHP and TOPSIS techniques to evaluate and compare the performances of Turkish banks. In this study, financial and non-financial performance variables are weighted by FAHP and then weighted scores are used to determine the bank ranking. Wanke, Azad, Barros, and Hassan (2016b) developed a model to determine efficiency factors in OECD banks using the TOPSIS method and quantile regression analysis. The results indicated that ownership, trend and origin effects on bank efficiency may change depending on the efficiency levels. Wu, Tzeng, and Chen (2009) used a hybrid method to measure the performance of the banks with FAHP, TOPSIS and VIKOR (multi-criteria optimization and compromise solution) by using a balanced scorecard. Gavurova, Belas, Kocisova, and Kliestik (2017) assessed the performances of Czech and Slovak banks using several multi-criteria decision-making tools. They applied SAW (simple averaging method), ORESTE, PROMETHEE and MAPPAC methods to compare 10 CAMEL benchmarks. The authors found out that all of the four methods yield similar results.

Aysan and Ceyhan (2008) investigated the determinants in measuring the performance of Turkish banks through regression analysis. They pointed out that the loan ratio and the bank capitalization affect the efficiency and performance of banks positively, while the effect of return on equity is not statistically significant. Assaf, Matousek, and Tsionas (2013) focused on measuring and comparing the productivity and efficiency of domestic and foreign Turkish banks by using Bayesian stochastic frontier analysis. The study shows the 
importance of NPLs (non-performing loans or bad loans) in estimating the model. Results of the study show that although there was a positive productivity change during 2002-2010, the change in mean efficiency of Turkish banks was negative. Doğan (2013) analyzed the performance of Turkish banks with the main indicators using the Grey relational analysis for 2005-2011. The results revealed that the best performing bank was Akbank. Another finding of the study was that the higher the ratio of Return on Assets, the higher the financial performance could be.

\section{METHODOLOGY}

This study offers a robust and easy-to-calculate model to evaluate bank performance using TOPSIS methodology combined with stepwise regression analysis. The data set covers the period of 2008-2018 and is obtained from 2019 Annual Report of Financial Ratios of The Banks Association of Turkey.

In the first stage, Turkish banks' performance is measured using a predetermined set of financial ratios (criteria). Following the first stage, stepwise regression is applied in the second stage to determine which criteria explain bank performance better. Before giving the results, the study will discuss the methodology. The next two sub-sections introduce the TOPSIS methodology and the stepwise regression technique sequentially. To prove the reliability of the two-stage analysis, BreuschPagan-Godfrey (BPG) test for heteroscedasticity, $Q^{2}$ test for autocorrelation, Phillips-Perron test and Augmented Dickey-Fuller test for unit root (stationarity) and Jarque-Bera test for normality are applied.

\subsection{TOPSIS method}

After being first introduced by Hwang and Yoon as a multi-criteria decision-making tool in 1981, TOPSIS has become one of the most preferred multi-criteria problem solving techniques. "The basic TOPSIS principle assumes that the chosen alternative should simultaneously have the shortest distance from the positive ideal solution and the farthest distance from the negative ideal solution" (Ertugrul \& Karakasoglu, 2009; Barros
\& Wanke, 2015; Wanke, Azad, \& Barros, 2016a). Within the framework of bank performance, the positive ideal solution may refer to profit maximization or cost minimization. On the other hand, the negative ideal solution may refer to profit minimization or cost maximization.

The methodology is summarized step by step as follows (Wanke, Azad, \& Barros, 2016a):

1. Formulation of an initial matrix, which consists of $m$ alternatives and $n$ criteria.

2. Calculation of normalized matrix by applying the equation below:

$r_{i j}=\frac{x_{i j}}{\sqrt{\sum_{i=1}^{m} x_{i j}^{2}}}, i=1,2, . . m$ and $j=1,2, \ldots n$,

where $x_{i j}$ represents the decision matrix and $r_{i j}$ represents the normalized matrix.

3. Calculation of weighted normalized matrix (if there are weights) for performance evaluation:

$$
W=\left(w_{i j}\right)_{m x n}=\left(w_{j} r_{i j}\right)_{m x n},
$$

where $w_{j}$ indicates the priority (weight) of the criteria $j$ and the summation of the weights is equal to 1 .

4. Determination of solutions that give positive ideal and negative ideal values. These are defined as the best and worst alternatives, respectively:

$$
\begin{aligned}
& A_{a}=\left\{\operatorname { m i n } \left(w_{i j} \mid i=1,2, \ldots, m, j \in J_{+},\right.\right. \\
& \max \left(w_{i j}|i=1,2, \ldots, m| j \in J_{-},\right\}= \\
& =\left\{\alpha_{a j} \mid j=1,2, \ldots, m\right\} \\
& A_{b}=\left\{\operatorname { m a x } \left(w_{i j} \mid i=1,2, \ldots, m, j \in J_{+},\right.\right. \\
& \min \left(w_{i j}|i=1,2, \ldots, m| j \in J_{-}\right\}= \\
& =\left\{\alpha_{a j} \mid j=1,2, \ldots, m\right\},
\end{aligned}
$$

where

$$
J_{+}=\{j \mid j \in \text { positive }\} \text { and } J_{-}=\{j \mid j \in \text { negative }\}
$$


represent positive attributes such as benefit, and negative attribute such as cost, respectively.

5. Calculation of distances between positive ideal solution $\left(d_{i a}\right)$ and negative ideal solution $\left(d_{i b}\right)$ :

$$
\begin{aligned}
& d_{i a}=\sqrt{\sum_{j=1}^{n}\left(x w_{i j}-\alpha_{a j}\right)^{2}}, i=1,2 \ldots, m, \\
& d_{i b}=\sqrt{\sum_{j=1}^{n}\left(x w_{i j}-\alpha_{b j}\right)^{2}}, i=1,2 \ldots, m .
\end{aligned}
$$

6. Calculation of similarities to an ideal solution:

$$
S_{i}=d_{i a} /\left(d_{i a}+d_{i b}\right)
$$

where $0 \leq S_{i} \leq 1, i=1,2, \ldots, m$.

7. Ranking the alternatives according to $S_{i}$ values, where a better alternative gives higher value of $S_{i}$.

\subsection{Stepwise regression}

Stepwise regression comprises both forward and backward selection techniques. Goldberger (1961) uses the parameters of the multiple linear regression model for estimating a stepwise procedure as follows:

$$
y=X_{1} \beta_{1}+X_{2} \beta_{2}+\varepsilon .
$$

According to this study, variables and coefficients are determined as below: $y$ is the dependent variable in the multivariate model and $X_{1}$ is the $N$ x $K_{1}$ matrix of observations on the first $K_{1}$ regressors: $\mathrm{x}_{\mathrm{i}}$ $\left(i=1, \ldots, K_{1}\right), \beta_{1}$ is the $K_{1} \times 1$ vector of coefficients of the first $K_{1}$ regressors, $X_{2}$ is the $N \times K_{2}$ matrix of observations on the second $\mathrm{K}_{2}$ regressors: $x_{j}(j$ $\left.=K_{1}+1, \ldots, K_{1}+K_{2}\right), \beta_{2}$ is the $K_{2} \times 1$ vector of coefficients of the second $K_{2}$ regressors, and $\varepsilon$ is the $N \mathrm{x}$ 1 vector of disturbances.

On the other hand, the stepwise least-squares procedure first estimates $\beta_{1}$, then regresses the residuals. After this process, $\beta_{2}$ is estimated using matrix inversions. In the stepwise regression analysis, the variables are added one by one in every single step, where new variables and the existing ones are checked for their significance. No significant variables are eliminated from the model. Stepwise regression includes two significance levels for the entering and removing variables. The variable selections continue until all variables in the model meet the significance levels (Rawlings, Pantula, \& Dickey, 1998).

\section{RESULTS AND DISCUSSION}

In this study, ten commercial banks with the highest market share are selected for analysis and comparison with between 2008 and 2018. The distribution of these banks is as follows: three stateowned banks, four private domestic banks and three foreign-owned banks. Table 1 lists the banks and their ownership structure.

Table 1. Turkish banks included in the study

Source: The Banks Association of Turkey (2019).

\begin{tabular}{l|c|c}
\hline \multicolumn{1}{c|}{ Bank name } & Acronym & Ownership \\
\hline Ziraat Bank & ZB & State \\
\hline Halk Bank & HB & State \\
\hline Vakiflar Bank & VB & State \\
\hline Akbank & AB & Private domestic \\
\hline Turkish Economy Bank & TEB & Private domestic \\
\hline Is Bank & IB & Private domestic \\
\hline Yapı Kredi Bank & YKB & Private domestic \\
\hline Deniz bank & DB & Foreign \\
\hline QNB Finans bank & ONB & Foreign \\
\hline Garanti Bank & GB & Foreign \\
\hline
\end{tabular}

The data set is compiled from The Banks Association of Turkey, an Annual Report of Financial Ratios (2019). Financial ratios are expressed in seven groups: capital ratios, balance-sheet ratios, asset quality, liquidity, profitability, income-expenditure structure and activity ratios. Selected financial ratios (criteria) and their structures (maximization or minimization criteria) are listed in Table 2. 
Table 2. Financial performance criteria

Source: The Banks Association of Turkey (2019).

\begin{tabular}{|c|c|c|}
\hline $\begin{array}{l}\text { Criteria } \\
\text { groups }\end{array}$ & Financial ratios (sub-criteria) & $\begin{array}{l}\text { Max/ } \\
\text { Min }\end{array}$ \\
\hline \multirow{3}{*}{$\begin{array}{l}\text { Capital } \\
\text { ratios }\end{array}$} & Capital adequacy ratio & $\operatorname{Max}$ \\
\hline & Shareholders' equity/Total assets & Max \\
\hline & $\begin{array}{l}\text { (Shareholders' equity - Permanent } \\
\text { assets)/Total assets }\end{array}$ & Max \\
\hline \multirow{2}{*}{$\begin{array}{l}\text { Balance- } \\
\text { sheet ratios }\end{array}$} & Funds borrowed/Total assets & Min \\
\hline & Total deposits/Total assets & Min \\
\hline \multirow{3}{*}{ Asset quality } & Financial assets (net)/Total assets & Max \\
\hline & Total loans/Total assets & Max \\
\hline & Loans under follow-up (gross)/Total loans & Min \\
\hline \multirow{2}{*}{ Liquidity } & Liquid assets/Total assets & Max \\
\hline & Liquid assets/Short-term liabilities & Max \\
\hline \multirow{2}{*}{ Profitability } & Average return on assets & Max \\
\hline & Average return on shareholders' equity & Max \\
\hline \multirow{4}{*}{$\begin{array}{l}\text { Income- } \\
\text { expenditure } \\
\text { structure }\end{array}$} & $\begin{array}{l}\text { Net interest income after specific } \\
\text { provisions/Total assets }\end{array}$ & Max \\
\hline & $\begin{array}{l}\text { Net interest income after specific } \\
\text { provisions/Total operating income }\end{array}$ & Max \\
\hline & Interest expense/Total assets & Min \\
\hline & Non interest income (net)/Total assets & Max \\
\hline $\begin{array}{l}\text { Activity } \\
\text { ratios }\end{array}$ & $\begin{array}{l}\text { Personnel expenses + Reserve for } \\
\text { employee termination benefit/Total } \\
\text { assets }\end{array}$ & Min \\
\hline
\end{tabular}

These financial ratios will be used in TOPSIS analysis to determine banks' first performance scores. The weights of criteria are equally treated in the model. Also, these ratios will be used in stepwise regression analysis as independent variables. The financial ratios included in the models are shown in the descriptive statistics in Table 3.
In this scope, mean, minimum, maximum and standard deviation are given for each criterion in Table 3. After providing descriptive statistics, the results of the first stage of the TOPSIS analysis are indicated in Tables 4 and 5. Table 4 shows the bank performance scores and Table 5 gives the first stage bank rankings.

According to the first stage, ZB's performance score in 2015 is found 0.7717 , which is the highest value, and this bank's performance mean is the second rank in the 2008-2018 period. While the lowest first stage mean performance score belongs to $\mathrm{DB}$ with $0.3598, \mathrm{AB}$ has the highest mean of 0.6500 . The first stage bank rankings are shown in Table 5.

According to the first stage analysis, the first and second ranks are shared between three banks $(A B$, $\mathrm{ZB}$, and GB) in the 2008-2018 period. These banks have the top three mean performance scores for this period. Four different banks (YKB, QNB, TEB, and $\mathrm{DB}$ ) are ranked as worst in different years of the period analyzed. These banks are also at the bottom in terms of the mean performance scores.

Afterwards, stepwise regression is applied to determine the criteria that explain performance better. The stepwise regression analysis results are shown in Table 6.

According to stepwise regression analysis results, 11 of the 17 criteria are significant at the $1 \%, 5 \%$ or

Table 3. Descriptive statistics of financial ratios (criteria)

\begin{tabular}{|c|c|c|c|c|}
\hline Criteria (financial ratios) & Mean & Min. & Max. & St. dev. \\
\hline Capital adequacy ratio & 16.0809 & 12.800 & 23.2000 & 2.0409 \\
\hline Shareholders' equity/Total assets & 10.8755 & 0.7000 & 15.5000 & 1.8621 \\
\hline Shareholders' equity - Permanent assets/Total assets & 7.6145 & 2.5000 & 13.9000 & 2.0278 \\
\hline Funds borrowed/Total assets & 10.1491 & 0.0000 & 23.8000 & 4.3090 \\
\hline Financial assets (net)/Total assets & 22.5609 & 7.3000 & 57.0000 & 9.8301 \\
\hline Total loans/Total assets & 60.9146 & 29.5000 & 73.9000 & 8.1036 \\
\hline Loans under follow-up (gross)/Total loans & 3.6536 & 1.2000 & 8.30000 & 1.5593 \\
\hline Liquid assets/Total assets & 26.4827 & 8.6000 & 60.5000 & 8.2322 \\
\hline Liquid assets/Short-term liabilities & 46.3000 & 14.0000 & 79.3000 & 13.3141 \\
\hline Average return on assets & 1.7518 & 0.7000 & 3.1000 & 0.5502 \\
\hline Average return on shareholders' equity & 16.1418 & 6.9000 & 39.6000 & 5.2942 \\
\hline Net interest income after specific provisions/Total assets & 3.1755 & 1.3000 & 6.0000 & 0.7725 \\
\hline Net interest income after specific provisions/Total operating income & 59.4582 & 36.6000 & 87.7000 & 10.1644 \\
\hline Total deposits/Total assets & 61.6909 & 52.0000 & 83.2000 & 6.1485 \\
\hline Interest expense/Total assets & 4.6682 & 2.9000 & 9.1000 & 1.3533 \\
\hline (Personnel expenses + Reserve for employee termination benefit)/Total assets & 1.0746 & 0.5000 & 2.4000 & 0.3595 \\
\hline Non-interest income (net)/Total assets & 2.2082 & 0.1000 & 82.3000 & 7.7290 \\
\hline
\end{tabular}


Table 4. Performance scores of the first stage

\begin{tabular}{|c|c|c|c|c|c|c|c|c|c|c|c|c|}
\hline Banks & 2008 & 2009 & 2010 & 2011 & 2012 & 2013 & 2014 & 2015 & 2016 & 2017 & 2018 & $\begin{array}{c}\text { Mean } \\
\text { of the bank }\end{array}$ \\
\hline ZB & 0.4543 & 0.6331 & 0.6187 & 0.5999 & 0.6004 & 0.7105 & 0.7254 & 0.7717 & 0.7052 & 0.6820 & 0.5203 & 0.6383 \\
\hline$H B$ & 0.3789 & 0.5343 & 0.4974 & 0.5616 & 0.5293 & 0.6180 & 0.4812 & 0.5083 & 0.4551 & 0.5181 & 0.4278 & 0.5009 \\
\hline VB & 0.3731 & 0.5221 & 0.4280 & 0.4370 & 0.4062 & 0.4572 & 0.4603 & 0.4574 & 0.4171 & 0.4487 & 0.4850 & 0.4447 \\
\hline$A B$ & 0.3958 & 0.6300 & 0.6593 & 0.6081 & 0.6306 & 0.6993 & 0.7311 & 0.7009 & 0.7250 & 0.7578 & 0.6120 & 0.6500 \\
\hline TEB & 0.3135 & 0.3941 & 0.3741 & 0.3386 & 0.3774 & 0.4393 & 0.3681 & 0.4508 & 0.3948 & 0.3764 & 0.5237 & 0.3955 \\
\hline IB & 0.3519 & 0.5211 & 0.5321 & 0.5483 & 0.5422 & 0.5933 & 0.6293 & 747 & 0.5 & 0.5520 & 0.4581 & 0.5353 \\
\hline YKB & 0.3073 & 0.4475 & 0.4597 & 0.4499 & 0.4182 & 0.5537 & 0.4469 & 4151 & 0.3513 & 0.4164 & 0.5267 & 0.4357 \\
\hline DB & 0.3130 & 0.3595 & 0.3072 & 0.4690 & 0.4609 & 0.3201 & 0.3327 & 3160 & 0.3482 & 0.3223 & 0.4082 & 0.3598 \\
\hline QNB & 0.3094 & 0.4878 & 0.4502 & 0.4658 & 0.3399 & & & & & & 0.4795 & 0.4129 \\
\hline GB & 0.6827 & 0.5769 & 0.5582 & 0.5855 & 0.5142 & 0.5625 & 0.5759 & 0.5911 & 0.5758 & 0.6188 & 0.6416 & 0.5894 \\
\hline
\end{tabular}

Table 5. Rankings of banks at the first stage

\begin{tabular}{|c|c|c|c|c|c|c|c|c|c|c|c|}
\hline Ranking & 2008 & 2009 & 2010 & 2011 & 2012 & 2013 & 2014 & 2015 & 2016 & 2017 & 2018 \\
\hline 1 & GB & ZB & $A B$ & $A B$ & $A B$ & ZB & $A B$ & ZB & $A B$ & $A B$ & GB \\
\hline 2 & ZB & $A B$ & $\mathrm{ZB}$ & $\mathrm{ZB}$ & $\mathrm{ZB}$ & $A B$ & ZB & $A B$ & ZB & $\mathrm{ZB}$ & $A B$ \\
\hline 3 & $A B$ & GB & GB & GB & $\mathrm{IB}$ & $\mathrm{HB}$ & $\mathrm{IB}$ & GB & $\mathrm{IB}$ & GB & YKB \\
\hline 4 & $\mathrm{HB}$ & $\mathrm{HB}$ & $\mathrm{IB}$ & $\mathrm{HB}$ & $\mathrm{HB}$ & $\mathrm{IB}$ & GB & $\mathrm{IB}$ & GB & $\mathrm{IB}$ & TEB \\
\hline 5 & VB & VB & $\mathrm{HB}$ & IB & GB & GB & $\mathrm{HB}$ & $\mathrm{HB}$ & $\mathrm{HB}$ & $\mathrm{HB}$ & $\mathrm{ZB}$ \\
\hline 6 & $\mathrm{IB}$ & $\mathrm{IB}$ & YKB & DB & DB & YKB & VB & VB & VB & VB & VB \\
\hline 7 & TEB & QNB & QNB & QNB & YKB & VB & YKB & TEB & QNB & YKB & QNB \\
\hline 8 & $\mathrm{DB}$ & YKB & VB & YKB & VB & TEB & QNB & YKB & TEB & QNB & $\mathrm{IB}$ \\
\hline 9 & QNB & TEB & TEB & VB & TEB & QNB & TEB & QNB & YKB & TEB & $\mathrm{HB}$ \\
\hline 10 & YKB & DB & DB & TEB & QNB & DB & DB & DB & DB & DB & DB \\
\hline
\end{tabular}

Table 6. Stepwise regression analysis results

\begin{tabular}{|c|c|c|c|}
\hline Variable & Coefficient & Std. error & t-statistic \\
\hline Shareholders' equity/Total assets & $0.0077 * *$ & 0.0369 & 2.0776 \\
\hline Financial assets (net)/Total assets & $0.0078^{*}$ & 0.0012 & 6.3745 \\
\hline Loans under follow-up (gross)/Total Loans & $-0.0279 *$ & 0.0041 & -6.8010 \\
\hline Total loans/Total assets & $0.0874^{*}$ & 0.0012 & 7.4892 \\
\hline $\begin{array}{l}\text { Personnel expenses + Reserve for employee termination benefit/Total } \\
\text { assets }\end{array}$ & $-0.0818^{*}$ & 0.0216 & -3.7882 \\
\hline Liquid assets/Short-term liabilities & $0.0028^{*}$ & 0.0005 & 5.7219 \\
\hline Average return on shareholders' equity & $0.0063^{*}$ & 0.0016 & 3.8814 \\
\hline Funds borrowed/Total assets & $-0.0073^{*}$ & 0.0021 & -3.4735 \\
\hline Total deposits/Total assets & $-0.0035 * *$ & 0.0014 & -2.4791 \\
\hline Non-interest income (net)/Total assets & $0.0018^{* *}$ & 0.0008 & 2.4120 \\
\hline Interest expense/Total assets & $-0.0115^{* * *}$ & 0.0061 & -1.8828 \\
\hline$R^{2}=0.7768-$ Adjusted $R^{2}=0.7542$ & & & \\
\hline
\end{tabular}

Note: ${ }^{*}$ - statistical significance at the $1 \%$ level; $* *$ - statistical significance at the $5 \%$ level; *** - statistical significance at the $10 \%$ level.

$10 \%$ levels. Although the positive coefficient of the negative coefficients indicate a negative relationcriterion corresponds to the positive relationship ship. Equation (9), shows the regression analysis between this criterion and the performance score, formula.

Banking performance scores $=(0.0077 \cdot$ Shareholders' equity/Total assets $)+$ $+(0.0078 \cdot$ Financial assets (net)/Total assets $)-$

- $(0.0279 \cdot$ Loans under follow-up (gross $) /$ Total loans $)+(0.0874 \cdot$ Total loans/Total assets $)-$

(0.0818 Personnel expenses + Reserve for employee termination benefit/Total assets $)+$

$(0.028 \cdot$ Liquid assets/Short-term liabilities $)+(0.0063 \cdot$ Average return on shareholders' equity $)-$

$(0.0073 \cdot$ Funds borrowed/Total assets $)-(0.0035 \cdot$ Total deposits/Total assets $)+$

$(0.0018 \cdot$ Non-interest income $($ net $) /$ Total assets $)-(0.0115 \cdot$ Interest expense/Total assets $)$. 
Econometric assumptions for the stepwise regression model are verified by diagnostic and stationarity tests, and the results are given in Tables 7 and 8 , respectively.

Table 7. Diagnostic test results

\begin{tabular}{l|c|c}
\hline \multicolumn{1}{c|}{ Test statistics } & F stat. & $\boldsymbol{N} \cdot \boldsymbol{R}^{\mathbf{2}}$ \\
\hline Breusch-Pagan-Godfrey & 1.1521 & 12.5958 \\
\hdashline Test statistics & Q-stat & Prob. \\
\hdashline$Q^{2}(5)$ & 8.5157 & 0.1300 \\
\hdashline Test statistics & Test score & Prob. \\
\hdashline Jarque-Bera & 3.5049 & 0.1734 \\
\hline
\end{tabular}

The study applies Breusch-Pagan-Godfrey (BPG) test and $Q^{2}$ test to check heteroskedasticity and autocorrelation problems in the stepwise regression model. Null hypotheses are tested: "There are no heteroskedasticity problems" with the BPG test and "There are no autocorrelation problems" with the $\mathrm{Q}^{2}$ test. According to test results, two hypotheses cannot be rejected at the significance levels $(1 \%$, $5 \%$, and $10 \%)$. Therefore, there are no heteroskedasticity or autocorrelation problems in the model. The normality of banking performance scores is also checked using the Jarque-Bera test. According to the test results, the dependent variable shows the normal distribution at all significance levels. After conducting diagnostic tests, the bank performance scores used in modelling stationarity are measured using Phillips-Perron (PP) and Augmented Dickey-Fuller (ADF) unit root tests.

Table 9. Performance scores of the second stage
Table 8. Stationarity test results

\begin{tabular}{|c|c|c|c|}
\hline & Tests & Test statistic & Probability \\
\hline \multirow{2}{*}{ ADF } & Intercept & $-4.3638^{*}$ & 0.0006 \\
\hline & Trend and Intercept & $-4.6581^{*}$ & 0.0014 \\
\hline \multirow{2}{*}{ PP } & Intercept & $-4.4040^{*}$ & 0.0005 \\
\hline & Trend and Intercept & $-4.7853^{*}$ & 0.0009 \\
\hline
\end{tabular}

Note: ${ }^{*}$ - statistical significance at the $1 \%$ level.

Table 8 shows the results of two different unit root tests with intercept and with trend and intercept applied to the level banking activity. In the unit root tests performed, the null hypothesis: "A dependent variable has a unit root" is tested using $\mathrm{ADF}$ and PP tests. If the null hypothesis is not rejected, it means that the variable has a stationarity problem. The score of ADF and PP unit test statistics corresponding to probabilities showed that all hypotheses were rejected at $1 \%$ level and all these values are significant. As a result, the dependent variable does not contain a unit root and corresponds to the stationarity condition.

The stepwise regression model corresponds to the econometric assumptions. Therefore, the study continues analyses with these 11 criteria and the performances of the banks are recalculated using the TOPSIS method with these refined criteria. Table 9 indicates the second stage of the TOPSIS results.

The average scores of Turkish banks are in the depth of the year 2008. After the 2008 global financial crisis, the scores rose by about $40 \%$ and were

\begin{tabular}{|c|c|c|c|c|c|c|c|c|c|c|c|c|}
\hline Banks & 2008 & 2009 & 2010 & 2011 & 2012 & 2013 & 2014 & 2015 & 2016 & 2017 & 2018 & $\begin{array}{l}\text { Mean of } \\
\text { the bank }\end{array}$ \\
\hline$Z B$ & 0.4502 & 0.6400 & 0.6362 & 0.6385 & 0.6460 & 0.7430 & 0.7101 & 0.7847 & 0.7055 & 0.6766 & 0.4793 & 0.6464 \\
\hline $\mathrm{HB}$ & 0.3792 & 0.5733 & 0.5292 & 0.5832 & 0.5832 & 0.6365 & 0.5040 & 0.5518 & 0.5011 & 0.6092 & 0.5224 & 0.5430 \\
\hline VB & 0.3572 & 0.5391 & 0.4625 & 0.4682 & 0.4560 & 0.4922 & 0.5077 & 0.5138 & 0.4519 & 0.4957 & 0.5462 & 0.4810 \\
\hline$A B$ & 0.3656 & 0.6197 & 0.6461 & 0.6036 & 0.6558 & 0.7232 & 0.7449 & 0.7419 & 0.7533 & 0.7823 & 0.6007 & 0.6579 \\
\hline TEB & 0.2805 & 0.4039 & 0.3799 & 0.3377 & 0.4077 & 0.4617 & 0.3568 & 0.4411 & 0.3643 & 0.2778 & 0.4223 & 0.3758 \\
\hline IB & 0.3302 & 0.5704 & 0.5943 & 0.6186 & 0.6286 & 0.6542 & 0.6747 & 0.6416 & 0.6272 & 0.5841 & 0.4117 & 0.5760 \\
\hline YKB & 0.3239 & 0.5077 & 0.5287 & 0.4882 & 0.4719 & 0.5427 & 0.4880 & 0.4807 & 0.3883 & 0.4647 & 0.5504 & 0.4759 \\
\hline DB & 0.2726 & 0.3182 & 0.2848 & 0.4325 & 0.4058 & 0.3565 & 0.3499 & 0.3509 & 0.3550 & 0.3328 & 0.4562 & 0.3559 \\
\hline QNB & 0.2839 & 0.4616 & 0.3897 & 0.4260 & 0.3305 & 0.3801 & 0.4466 & 0.3838 & 0.4057 & 0.3408 & 0.3905 & 0.3854 \\
\hline $\mathrm{GB}$ & 0.7039 & 0.5719 & 0.5483 & 0.5811 & 0.5244 & 0.5659 & 0.5715 & 0.5970 & 0.5453 & 0.5606 & 0.6495 & 0.5836 \\
\hline $\begin{array}{l}\text { Mean } \\
\text { of the year }\end{array}$ & 0.3747 & 0.5206 & 0.5000 & 0.5178 & 0.5110 & 0.5556 & 0.5354 & 0.5487 & 0.5098 & 0.5125 & 0.5029 & - \\
\hline
\end{tabular}



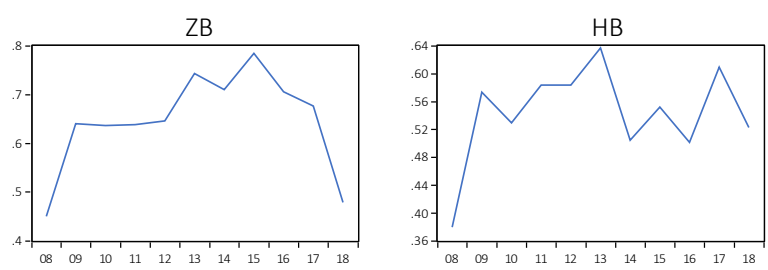

TEB
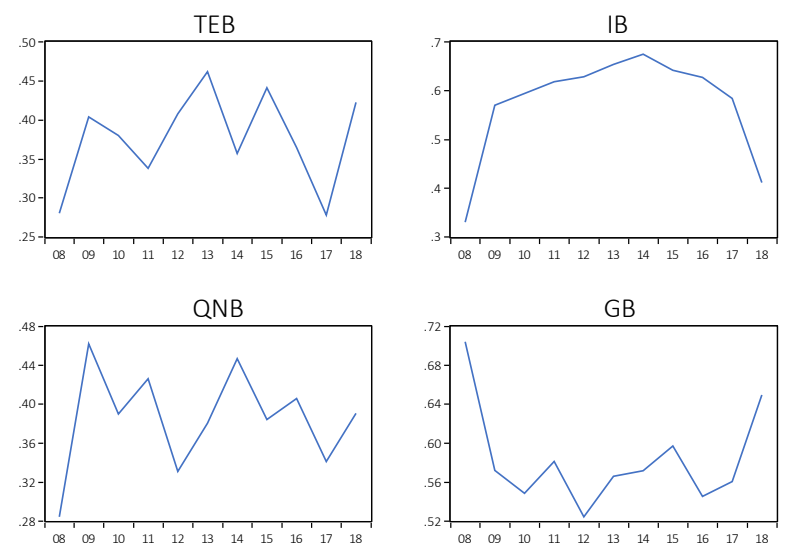
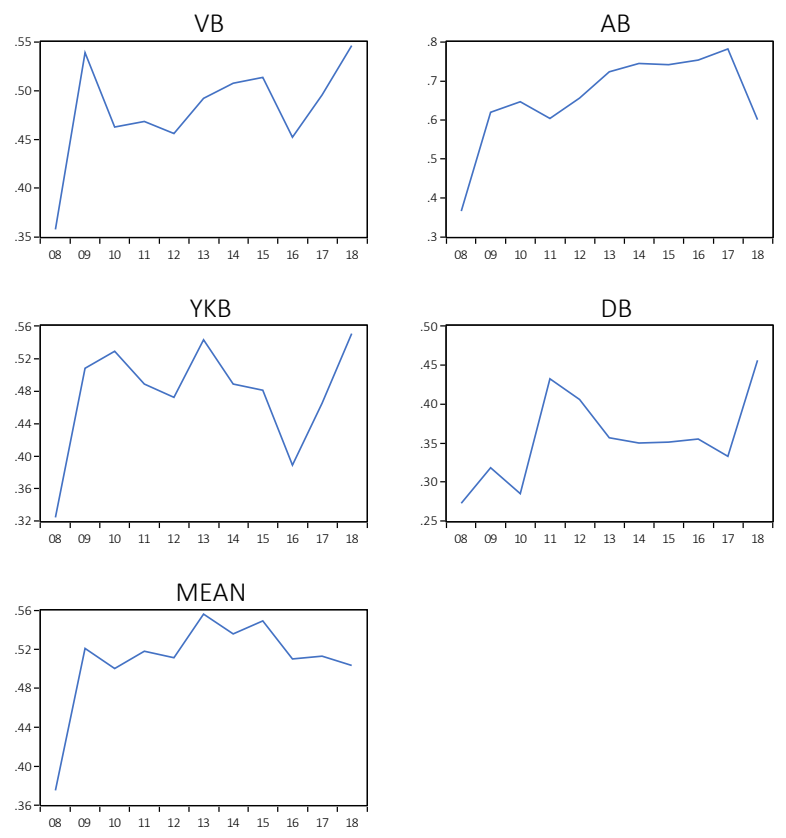

Figure 1. Performance scores for the second stage

rather stable through over 2009-2018. According to the second stage results, the 2015 ZB's performance score and the 2017 AB's performance score were more than 0.78 , which are the highest performance indicators for the whole analysis period. The average performance score in the 2008-2018 period is 0.6579 for $A B$, which is the highest. $\mathrm{ZB}$ and GB follow this bank. The mean performance scores of the rest of the banks from the highest to the lowest are IB, HB, VB, YKB, QNB, TEB, and $\mathrm{DB}$, respectively. Only the first two banks' ( $\mathrm{AB}$ and ZB) mean performances exceed $60 \%$ and each year these banks' indicators (except 2008 for two banks and 2018 for ZB) surpass this level. In three banks' (GB, IB, and $\mathrm{HB}$ ), mean performance scores vary from 0.50 to 0.60 . The lowest performance indi- cators for all banks (except TEB and GB) are observed in 2008. The bank performance estimates for the second stage are shown in Figure 1.

Figure 1 shows the scales of the bank performance in the left axis from 2008 to 2018 . All banks' performance increased after 2008 (except GB). After 2008 , on a yearly basis, the mean of all banks' performance exceeded 0.50. The ratings of banks at the second stage are shown in Table 10.

According to the second stage analysis, $\mathrm{AB}, \mathrm{ZB}$ or GB in 2008-2018 ranked first and the second (except 2011). Although the worst score for $A B$ is the fourth ranking in 2011, ZB is the sixth-ranked in 2018. GB ends in the fifth position three times be-

Table 10. Second stage rankings of banks

\begin{tabular}{|c|c|c|c|c|c|c|c|c|c|c|c|}
\hline Ranking & 2008 & 2009 & 2010 & 2011 & 2012 & 2013 & 2014 & 2015 & 2016 & 2017 & 2018 \\
\hline 1 & GB & ZB & $A B$ & ZB & $A B$ & ZB & $A B$ & ZB & $A B$ & $A B$ & GB \\
\hline 2 & ZB & $A B$ & ZB & IB & ZB & $A B$ & ZB & $A B$ & ZB & ZB & $A B$ \\
\hline 3 & $\mathrm{HB}$ & $\mathrm{HB}$ & IB & $A B$ & IB & IB & IB & IB & IB & $\mathrm{HB}$ & YKB \\
\hline 4 & $A B$ & GB & $\mathrm{GB}$ & $\mathrm{HB}$ & $\mathrm{HB}$ & $\mathrm{HB}$ & GB & GB & GB & IB & VB \\
\hline 5 & VB & IB & $\mathrm{HB}$ & GB & GB & GB & VB & $\mathrm{HB}$ & $\mathrm{HB}$ & GB & $\mathrm{HB}$ \\
\hline 6 & IB & VB & YKB & YKB & YKB & YKB & $\mathrm{HB}$ & VB & VB & VB & ZB \\
\hline 7 & YKB & YKB & VB & VB & VB & VB & YKB & YKB & QNB & YKB & $\mathrm{DB}$ \\
\hline 8 & QNB & QNB & QNB & DB & TEB & TEB & QNB & TEB & YKB & QNB & TEB \\
\hline 9 & TEB & TEB & TEB & QNB & DB & QNB & TEB & QNB & TEB & DB & IB \\
\hline 10 & DB & DB & DB & TEB & QNB & DB & DB & DB & DB & TEB & QNB \\
\hline
\end{tabular}


tween 2011 and 2013, this position being the worst ranking of GB in the analysis period. IB is ranked once in the second place and six times third in the 2010-2016 period. Only in 2011, it ranks second. However, in the first and the last two years of the analysis period, IB has different rankings, from fourth to ninth. HB's ranking changes be- tween the third and sixth positions. VB is ranked between fifth and seventh steadily. YKB shows a similar performance ranking to VB. Its ranking changes between sixth and eighth. DB and QNB ranked seventh in 2016 and 2018, respectively. These banks and TEB ranked ninth and last (except 2018) in different years of the analysis period.

\section{CONCLUSION}

This paper introduces the comparative performance analysis of 10 Turkish banks between 2008 and 2018 using a two-stage TOPSIS analysis and stepwise regression. Since the bank performance analysis includes several criteria that are often conflicting, determining the criteria that fit the financial data best is an important stage of assessments. This study aims to find out bank-specific characteristics, which explain and affect the performance most. The results of this study show that $\mathrm{AB}$ is the best performing bank with an average score of 0.6579 over 11 years. This result is similar to other studies on Turkish banks (Assaf, Matousek, \& Tsionas, 2013; Doğan,2013; Seçme, Bayrakdaroğlu, \& Kahraman, 2009). AB is followed by $\mathrm{ZB}$ and GB. According to the mean scores, the rankings order of the rest of the banks are given from the first to the last as IB, HB, VB, YKB, QNB, TEB, and DB. The mean score of Turkish banks is the lowest in 2008, since with the 2008 financial crisis, the Turkish banking system is vulnerable to external economic shocks. Although the average performance has increased after the crisis, it is rather low and stable through the years 2009 to 2018. The results of the stepwise regression analysis reveal that the loan ratio significantly and positively contributes to the bank performance, while non-performing loans have a similar effect in the opposite direction. The results are parallel to previous research (Assaf, Matousek, \& Tsionas, 2013; Aysan \& Ceyhan, 2008). Indeed, the allocation and management of loans are critical for managers and decision makers. Expenses were other critical criteria in financial performance. The results of the stepwise regression analysis indicate that both personnel and interest expenses have a serious negative effect on bank performance.

In this study, the process of bank performance evaluation is seen as a multi-criteria decision-making problem. The proposed model is based on maximum-minimum criteria instead of traditional input-output oriented approach. In the second step analysis, only the criteria that best describe the model are included in the calculation of the final performance scores. This methodology allows measuring and benchmarking the bank performance in a stronger, more flexible and informative manner. The model can be used to analyze bank performance in other developing countries. Further studies may include making cross-country comparisons with the same methodology or a combination of various techniques.

\section{REFERENCES}

1. Akyüz, Y., \& Boratav, K. (2003) The Making of Turkish Financial Crisis. World development, 31(9), 1549-1566. https:// doi.org/10.1016/S0305750X(03)00108-6

2. Alper, C. E., \& Öniş, Z. (2004). The Turkish Banking System and the IMF in the Age of Capital Account Liberalization. New Perspectives on Turkey, 30, 25-55. https://doi.org/10.1017/ S0896634600003903
3. Assaf, A. G., Matousek, R., \& Tsionas, E. G. (2013). Turkish bank efficiency: Bayesian estimation with undesirable outputs. Journal of Banking \& Finance, 37(2), 506-517. https:// doi.org/10.1016/j.jbankfin.2012.09.009

4. Aysan, A. F., \& Ceyhan, Ș. P. (2008). What determines the banking sector performance in globalized financial markets? The case of Turkey. Physica
A: Statistical Mechanics and its Applications, 387(7), 15931602. https://doi.org/10.1016/j. physa.2007.11.003

5. Barros, C. P., \& Wanke, P. (2015). An analysis of African airlines efficiency with two-stage TOPSIS and neural networks. Journal of Air Transport Management, 44, 90-102. https://doi.org/10.1016/j. jairtraman.2015.03.002

6. Berger, A. N., \& Humphrey, D. B. (1997). Efficiency of financial 
institutions: International survey and directions for future research. European Journal of Operational Research, 98(2), 175-212. https://doi.org/10.1016/S03772217(96)00342-6

7. Chao, C., Yu, M., \& Wu, H. (2015). An application of the dynamic network DEA Model: The case of banks in Taiwan. Emerging Markets Finance and Trade, 51(1), 133-151. https://doi.org/10.1080/1 540496X.2014.998887

8. Doğan, M. (2013). Measuring Bank Performance with Gray Relational Analysis: The Case of Turkey. Ege Akademik Bakış Dergisi, 13(2), 215-226.

9. Dong, Y., Firth, M., Hou, W., \& Yang, W. (2016). Evaluating the performance of Chinese commercial banks: A comparative analysis of different types of banks. European Journal of Operational Research, 252(1), 280-295. https:// doi.org/10.1016/j.ejor.2015.12.038

10. Doumpos, M., \& Zopounidis, C. (2010). A multicriteria decision support system for bank rating. Decision Support Systems, 50(1), 55-63. https://doi.org/10.1016/j. dss.2010.07.002

11. Ertugrul, I., \& Karakasoglu, N. (2009) Performance Evaluation of Turkish Cement Firms with Fuzzy Analytic Hierarchy Process and TOPSIS Methods. Expert Systems with Applications, 36, 702715. http://dx.doi.org/10.1016/j. eswa.2007.10.014

12. Fernandes, F. D. S., Stasinakis, C., \& Bardarova, V. (2018). Twostage DEA-Truncated Regression: Application in banking efficiency and financial development. Expert Systems with Applications, 96, 284-301. https://doi.org/10.1016/j. eswa.2017.12.010

13. Fethi, M. D., \& Pasiouras, F. (2010). Assessing bank efficiency and performance with operational research and artificial intelligence techniques: A survey. European journal of operational research, 204(2), 189-198. https://doi. org/10.1016/j.ejor.2009.08.003

14. Fukuyama, H., \& Matousek, R. (2011). Efficiency of Turkish banking: Two-stage network system. Variable returns to scale model. Journal of International Financial Markets, Institutions and Money, 21(1), 75-91. https://doi. org/10.1016/j.intfin.2010.08.004

15. Gavurova, B., Belas, J., Kocisova, K., \& Kliestik, T. (2017). Comparison of selected methods for performance evaluation of Czech and Slovak commercial banks. Journal of Business Economics and Management, 18(5), 852-876. https://doi.org/10. 3846/16111699.2017.1371637

16. Goldberger, A. S. (1961). Stepwise least squares: residual analysis and specification error. Journal of the American Statistical Association, 56(296), 998-1000. Retrieved from https://www.jstor.org/ stable/2282011

17. Hsiao, C., Shen, Y. \& Bian, W. (2015). Evaluating the effectiveness of China's financial reform - The efficiency of China's domestic banks. China Economic Review, 35, 70-82. https://doi. org/10.1016/j.chieco.2015.05.006

18. Huang, T. H., Lin, C. I., \& Chen, K. C. (2017c). Evaluating efficiencies of Chinese commercial banks in the context of stochastic multistage technologies. PacificBasin Finance Journal, 41, 93-110. https://doi.org/10.1016/j. chieco.2015.05.006

19. Hwang, C. L., \& Yoon, K. (1981). Multiple attribute decision making. New York: Springer. Retrieved from https://www.springer.com/ gp/book/9783540105589

20. Lee, J. Y., \& Kim, D. (2013). Bank performance and its determinants in Korea. Japan and the World Economy, 27, 83-94. https://doi. org/10.1016/j.chieco.2015.05.006

21. Mandic, K., Delibasic, B., Knezevic, S., \& Benkovic, S (2014). Analysis of the financial parameters of Serbian banks through the application of the fuzzy AHP and TOPSIS methods. Economic Modelling, 43, 30-37. https://doi.org/10.1016/j.econmod.2014.07.036

22. Paradi, J. C., Rouatt, S., \& Zhu, H. (2011). Two-stage evaluation of bank branch efficiency using data envelopment analysis. Omega, 39(1), 99-109. https://doi. org/10.1016/j.omega.2010.04.002

23. Rawlings, J. O., Pantula, S. G., \& Dickey, D. A. (2001). Applied regression analysis: $a$ research tool. Springer Science \& Business Media. Retrieved from https://www.springer.com/gp/ book/9780387984544

24. Salim, R., Arjomandi, A., \& Seufert, J. H. (2016). Does corporate governance affect Australian banks' performance? Journal of International Financial Markets, Institutions and Money, 43, 113-125. https://doi. org/10.1016/j.intfin.2016.04.006

25. Sayılgan, G., \& Yildırım, O. (2009). Determinants of Profitability in Turkish Banking Sector: 20022007. International Research Journal of Finance and Economics, 28, 207-214. Retrieved from https://www.researchgate.net/ publication/289005488_Determinants_of_profitability_in_turkish_banking_sector_2002-2007

26. Seçme, N. Y., Bayrakdaroğlu, A., \& Kahraman, C. (2009). Fuzzy performance evaluation in Turkish banking sector using analytic hierarchy process and TOPSIS. Expert Systems with Applications, 36(9), 11699-11709. https://doi. org/10.1016/j.eswa.2009.03.013

27. Sekmen, T., Akkus, O., \& Siklar, I (2015). Competitive Conditions in the Turkish Banking Systems. Journal of Business, Economics and Finance, 4(1), 53-68. https:// doi.org/10.17261/Pressacademia.201519950

28. Staub, R. B., Souza, G. D. S., \& Tabak, B. M. (2010). Evolution of bank efficiency in Brazil: A DEA approach. European Journal of Operational Research, 202(1), 204-213. https://doi.org/10.1016/j. ejor.2009.04.025

29. Svitalkova, Z. (2014). Comparison and evaluation of bank efficiency in selected countries in EU. Procedia Economics and Finance, 12, 644-653. https://doi.org/10.1016/S22125671(14)00389-X 
30. The Banks Association of Turkey. (2019). The Banking System in Turkey: Selected Ratios. Retrieved from https://www.tbb.org.tr/en/ banks-and-banking-sector-information/statistical-reports/20

31. Titko, J., \& Jureviciene, D. (2013). DEA application at cross-country benchmarking: Latvian vs. Lithuanian banking sector. Procedia Social and Behavioral Sciences, 110, 11241135. https://doi.org/10.1016/j. sbspro.2013.12.959

32. Wang, K., Huang, W., Liu, Y., (2014). Efficiency measures of the Chinese commercial banking system using an additive two-stage
DEA. Omega 44, 5-20. https://doi. org/10.1016/j.omega.2013.09.005

33. Wanke, P., Azad, M. A. K., \& Barros, C. P. (2016a). Predicting efficiency in Malaysian Islamic banks: A two-stage TOPSIS and neural networks approach. Research in International Business and Finance, 36, 485498. https://doi.org/10.1016/j. ribaf.2015.10.002

34. Wanke, P., Azad, M. A. K., Barros, C. P., \& Hassan, M. K. (2016b). Predicting efficiency in Islamic banks: An integrated multicriteria decision making (MCDM) approach. Journal of International Financial Markets, Institutions and
Money, 45, 126-141. https://doi. org/10.1016/j.intfin.2016.07.004

35. Wanke, P., Azad, M. A. K., \& Barros, C. P. (2016c). Efficiency factors in OECD banks: A tenyear analysis. Expert Systems with Applications, 64, 208227. https://doi.org/10.1016/j. eswa.2016.07.020

36. Wu, H. Y., Tzeng, G. H., \& Chen, Y. H. (2009). A fuzzy MCDM approach for evaluating banking performance based on Balanced Scorecard. Expert Systems with Applications, 36(6), 1013510147. https://doi.org/10.1016/j. eswa.2009.01.005 